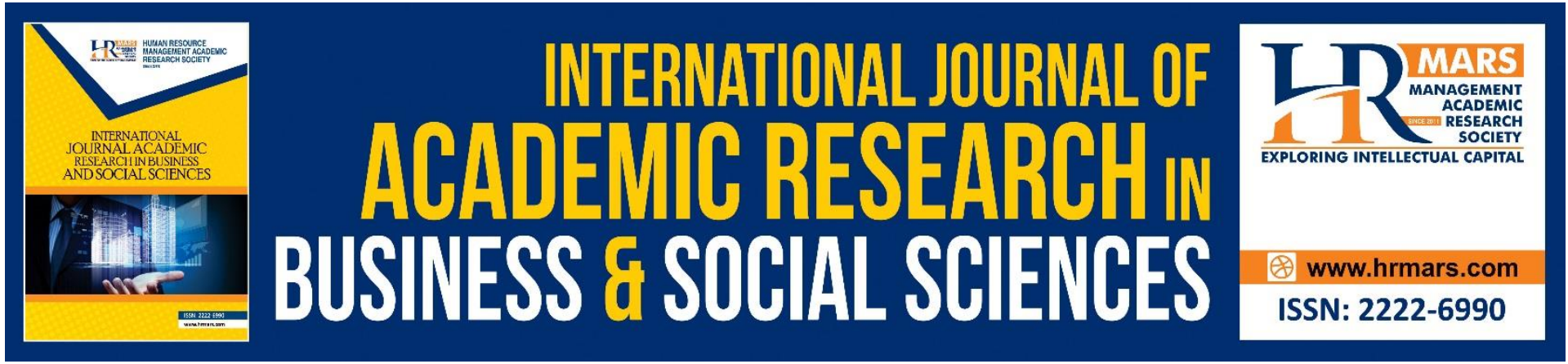

\title{
The Pattern of Development of Island Community Based on Cash for Work in Dendun Village, Bintan Region, Indonesia
}

Suyito, Norizan Abdul Ghani

To Link this Article: http://dx.doi.org/10.6007/IJARBSS/v11-i7/10415

DOI:10.6007/IJARBSS/v11-i7/10415

Received: 10 May 2021, Revised: 12 June 2021, Accepted: 24 June 2021

Published Online: 01 July 2021

In-Text Citation: (Suyito \& Ghani, 2021)

To Cite this Article: Suyito, \& Ghani, N. A. (2021). The Pattern of Development of Island Community Based on Cash for Work in Dendun Village, Bintan Region, Indonesia. International Journal of Academic Research in Business and Social Sciences, 11(7), 55-63.

Copyright: (c) 2021 The Author(s)

Published by Human Resource Management Academic Research Society (www.hrmars.com)

This article is published under the Creative Commons Attribution (CC BY 4.0) license. Anyone may reproduce, distribute, translate and create derivative works of this article (for both commercial and non-commercial purposes), subject to full attribution to the original publication and authors. The full terms of this license may be seen at: http://creativecommons.org/licences/by/4.0/legalcode

Vol. 11, No. 7, 2021, Pg. 55 - 63

http://hrmars.com/index.php/pages/detail/IJARBSS

JOURNAL HOMEPAGE

Full Terms \& Conditions of access and use can be found at http://hrmars.com/index.php/pages/detail/publication-ethics 


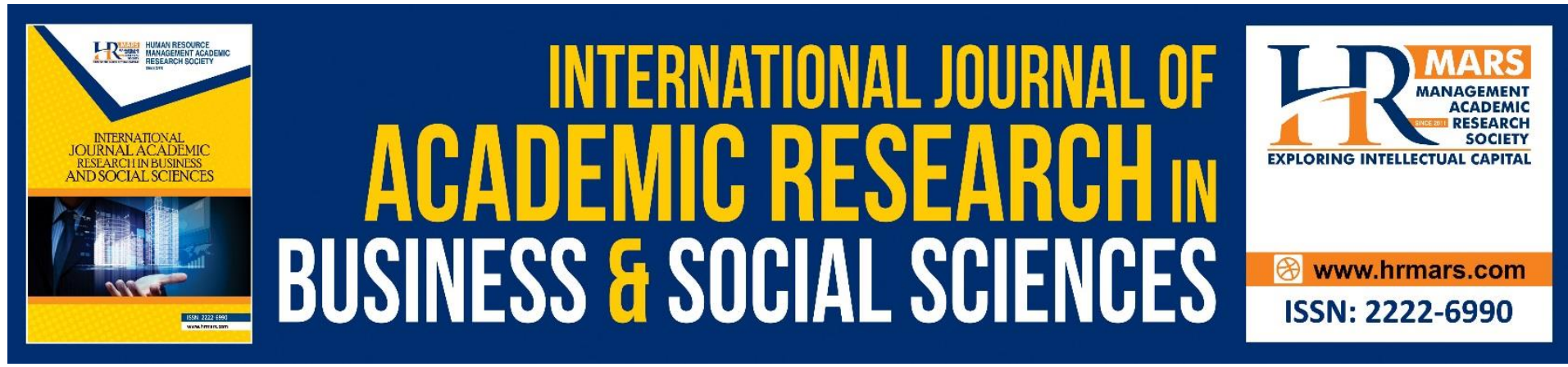

\title{
The Pattern of Development of Island Community Based on Cash for Work in Dendun Village, Bintan Region, Indonesia
}

\author{
Suyito \\ Institute For Policy Research (INSPIRE), Kepulauan Riau, Indonesia \\ Norizan Abdul Ghani (PhD) \\ Universiti Sultan Zainal Abidin, Terengganu, Malaysia \\ Email:norizabd@unisza.edu.my, Suyito1978@gmail.com
}

\begin{abstract}
This study is based on the progress of development pattern with cash for work basis in Dendun village, Bintan Region, Indonesia. The implementation of development is the regulations which is followed in village budgetary fund based on cash for work in Dendun village. The objective of this research is to investigate the development pattern of the island community based on cash for work in Dendun village. The method applied is qualitative by describing results from observation and interview at the site. The results of this research can be seen from community's participation in determining physical development by people needs. The involvement of people is started from their aspiration in the village meeting (Musdus) and stipulating their aspiration in the small town meeting (Musdes); the community development on cash for work basis allows in their participation to determine the target of development on a necessity basis. So, the island community has the authority to and feel represented for their aspiration. Job opportunities for the island community in a development program also being created, but it depends upon the third party in providing or supplying materials for Dendun village development where the consequence is the advantage for capital owners in the end.
\end{abstract}

Keywords: Community Development, Pattern of Community Development, Cash for Work Basis, Dendun Village, Bintan Region, Indonesia.

\section{Introduction}

The village fund is distributed by the central government for the development of villages in the region is significant in amount. The village fund is officially budgeted by the central government to local government; in 2015 as much as 20.7 trillion. It is effectively allocated in APBN 2015 as much as 20.7 trillion and has increased to a total amount of 46.98 trillion in the year of 2016 or increased $126.24 \%$ compared to village budget in 2015. In 2017, village funds increased to a total amount of 60 trillion rupiahs or $27.71 \%$ if we compare to village fund allocation in 2016, and it is still maintained in 2018. This village fund is allocated for 74.954 
villages with an average amount of 800 million of each village. Next, in 2019, the village fund is allocated 70 trillion or an increase up to $16.67 \%$ compared to 2018.

The sequence of significant budget increase from year to year is the manifestation of the fulfilment of villages' rights to perform village autonomy and empowering society in the village. This big village fund is the correct goal to empower local society by involving them in order to be able to give input as their aspiration for social interest as whatever developments in the village has to involve society. However, we often see in development processes that conflict happens because it is contradictive to local values. So, the society should be involved in every process of development in the village.

The government via the Coordinating Minister of Human Culture Development provides ideas to be concentrated in Cash For Work Program. This program can do infrastructural projects in developing Dendun village such as jetty development and road development by cementing. Such an act the village can be absorbed in financing social development. Not only observed in purchasing raw material but also this cash for work program, in the meantime, it can provide working opportunity in Dendun Village.

The geographical area of Dendun village is located in the middle of the sea; people must use a small boat called pompong to reach the village. This is a kind of small boat and equipped with a small engine and it becomes a public transportation for Dendun people who live on the island when they need to go ashore. This pompong can be occupied by two or three passengers who travel from traditional jetty belongs to local people.

The Map Of Dendun Island, Bintan Regency of Indonesia

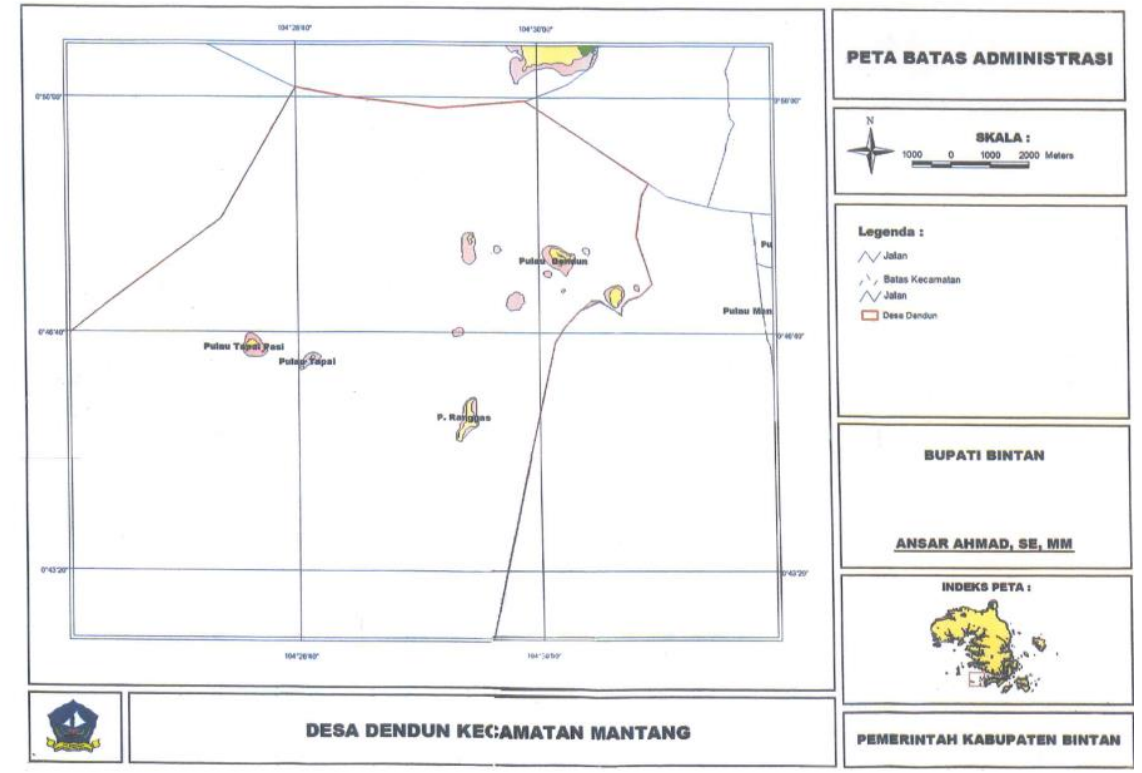

From the City Gurindam Tanjung Pinang, there is Pompong which transports passengers one way. It is one of the transportation assets belongs to the people of Dendun village to Tanjung Pinang or otherwise people making the trip to Tanjung Pinang using this kind of transportation to get their needs. The trip by the sea using pompong takes 40 minutes from Tanjung Pinang to Dendun. While other trips from another jetty can be departed from Batu Licin by using rental pompong which cost Rp 50000 for return, and it takes 20 minutes per trip. Dendun 
village, in district of Mantang has a small jetty and being administrated by the Bintan government. It is used by fishermen to anchor their boats. A hut is built to provide a place for loading or unloading activities after fishing.

\section{Literature Review}

This part will review some studies on cash for work in community development. Many researchers explain that implementation of cash for work will solve poverty in society and empowering community in some activities which will benefit them (Bekun \& Gani, 2013; Herdiana, 2019; Sumarto \& Dwiantara, 2019; Dian \& Maruf, 2019; Budiasa, Raka \& Mardika, 2020). However, this program will not permanently enhance the prosperity of society because this is only a temporary activity.

Herdiyana (2019) stated 'although this program is feasible to be continued, it needs improvement, including the selection of activity according to the flexible need of the village and enlargement of empowering society'. Cash for work program may involve social participation in using budgeted village fund (Manembu, Albert, Kusen \& Deeng, 2019). Then, in implementing government Policy for increasing farmers' prosperity through cash for work program for food in the district of Noemuti (2017). Program for food (PKP) planned by the government has not maximum implemented, because it has not given motivation and awareness for society on the importance of understanding of PKP has been done. The program is not effectively nor efficiently so in the third year of PKP program, it does not reach the target of land area RTS-PM to75 acres as stipulated in its implementation. The steps of controlling program implementation of cash for work has been running three times and it should be increased so that it can reach the proper target as planned toward farmers pension. Evaluation on food cash for work which runs on for village level or district level is expected to be implemented for regency level for the realization of inputs as concrete action is assumed as continuity to overcome the obstacles of implementing food in cash for work program.

On the other hand, the research was done by Dian \& Ma'ruf (2017) on empowering society through a case study of cash for work program at Plandaan Village, Tulungagung Region shows the result that empowering society of this village has run well, from the preparation up to socialization to workers. The next step is to analyse the proposal of activity priority. The alternative program absorbs social proposal but it is still minimum even their self-participation in society is quite high. The next formulation step is planning action on wages, but it does not follow the regulation.

Then, the next step is an implementation where workers perform their duties but this step has obstacles that the workers are not professional and it causes lateness. The evaluation step, controlling, and evaluation are done by an authorized party and proved through the final report. The termination step is the ending of this program; where society and village authority get benefits from this program.

The next research done by Raka \& Mardika (2019) related to the implementation of cash of work on the poor in Gianyar Village, concludes:

i. Implementation of cash for work has run well, as an implementation of priority of cash for work village fund financing activity, self-cash for work program, society involvement as self-implementation, cash payment on wages. 
ii. Supporting factors as government policy, labour availability, village institution, variety of works, and obstacles factor covering the harmonization of village planning and workers skill.

iii. The impact of implement any policy on cash for work for in the village is covering economic impact, social and culture.

It is also found that implementation cash for work is successful although the results has not fulfilled the procedure as found by Ynati (2019). It is caused by miscommunication among district government and the institution concerned, natural resources, and due to less guidance or socialization of the program to district government of Labuhan Tangga. Then, in the evaluation of strategy and implementation on continuity of cash for work program done in Regency Timor Tengah Utara by Dima (2016), stated the program has not been performed optimally. This condition encounters barriers of the availability natural resources. The strategy used in motivating continuity of the PKP program in the regency of Timur Tengah Utara is to enhance the intensity of counselling and forming of farmers group for improvement of their resources.

\section{Objective}

The objective of this research is to investigate the patterns of island community development on cash for work basis in Dendun village, Bintan Regency, Indonesia.

\section{Methodology}

This research is done by using the descriptive qualitative method. Location of the research is Dendun village, Bintan regency, Indonesia. The selection of research area based on considering that this zone can be categorized as the zone which is having a big potential to develop its economy. The strategic location which surrounded by the sea and its sea resources are abundant with small fish, prawns, crabs, squids, and so on. The Data is collected by indepth interviewing technique and observation, complete with data documentation from Dendun village. Data analysis is performed descriptively and qualitatively. In collecting primary data, the interview process is not structurally and observation is used to interview and observe native villagers in empowering their involvement in community development; because interviews and observation can give value added to the result of this research. The samples taken are purposive sampling based on a certain policy. The respondents in the research are native villagers of the island including the chief of the village, two staff at the village office, chief of Town Meeting Board, and 11 fishermen living in this village.

\section{Findings}

From the results of research, it is found that the patterns of community development are based on following cash for work:

\section{i. The Pattern of Village Mutual Approval}

In absorbing the people aspirations and stipulating people aspiration on small town meeting (Musdes) or village meeting (Musdus), cash for work basis is always considered as priority in Dendun Village. The small town meeting or Musdes in Dendun village is introduce as a mechanism to stipulate the most basic aspiration of people by doing the cash for work. The development based on village monetary fund ( $A D D$ ) is stipulated by government regulation. The Musdes done by Rt (neighbourhood authority) and Rw (peoples' authority) with the the 
early planning by the chief of Dendun village. This plan will firstly involve village community in the meeting to convey their thoughts and needs, concerning the development for people. The priority of development is focusing on the people of Dendun village. In the Musdes, the people aspirations which have been conveyed is stipulated in village mutual approval. The chief of Dendun village invited all the representatives such as community representatives, neighbourhood authority, as well as villagers, teachers, and paramedic representatives to determine the aspiration of Dendun people. These aspirations are started from village mutual agreement planning which is the nature of people participating in their need. Once the aspiration of people was abandoned so that people's aspiration on basic needs are not suitable with the policy implemented by the central government and regency government, such as freshwater refinery from seawater in Dendun village. Up to this present time, the assistance from the central government is not running smoothly nor functioning to people's need for freshwater. After the Musdes stipulation, it is brought to be discussed in village development and planning at the village hall. All representatives are attending this village development and planning agreement division. All people aspiration absorbed in people mutual agreement in which priority of activity budgeted by village fund (ADD) by running year budget. Then the result of village development planning agreement of Dendun village is recapitulated by Document of Budget implementation (DPA) for legalization through The Board of Empowering Village Development (BPMD) of Bintan Regency.

\section{ii. Planning from People to People and Local People, Material Fulfil by the Third Party}

We know that the process of community development in Dendun village is all well planned, participative, and transparent. For that purpose, the community development by the budgeted monetary fund of the village (ADD) should be based on cash for work basis, because it is all government regulation procedure. So that society aspiration can all absorbed, from the Musdus to the Musdes aspiration to achieve village development planning. All parties must involve, and finally the implementation of physical development should involve local people. Generally, Dendun communities are fishermen, who are busy with fishing activities with bigger income than their involvement in the Dendun village's development project. However, not all of them are involve in fishing activities, some involve in development works such as permanent jetty construction, cemented road, and sport facilities for local people. Those who involve in the development are usually those who do not afford complete fishing equipments and also outsiders who marry local women in Dendun. Nevertheless, what we can see and observe that development patterns must involve the third party in fulfilling materials for physical development in that place because the villagers cannot provide those materials. While physical development using the fund has to be based on cash for work, in practical, the provision material involves the third party to fulfil those materials for community development. From cement, sand, iron bricks, all fulfilled by the third party. However, before involving the third party the village government needs to have a consultation from the regency authority via community representative in order to perform the process. The materials from the third party then transported by middle size boat to the island which takes 30 minutes from the harbour and it causes additional cost from loading to truck till it reaches Dendun village. All need more cost in the process. Sometimes government should be fair and wise with the fund allocation on which archipelago basis. Different from villages on mainland, the problem encountered in Dendun in providing materials where it still depends on the third party and having additional cost due to the transportation cost. 


\section{iii. The Characteristic of Development is Always in Accordance to Priority Needs of Community}

The aspiration from the lowest level up to the highest level are all based on the needs of village development of Dendun, which is differ from the Top-Down development pattern. The Top-Down pattern is not beneficial for local people. Hence, the development is abounding up to this moment. By having village monetary fund (ADD) with cash for work basis, recent development must be based on the bottom-up characteristic, for instance, the development of jetty in every neighbourhood which was not permanent. After applying village monetary fund on cash for work basis, the jetties on the island are built permanently. The next priority based on the local community needs such as developing or upgrading roads through cementing, people can utilise the improved roads compared to what they use to be. They also need fresh and hygiene water from a well for their daily usage which also included as one of community development projects. The task for getting freshwater is normally done by women. One of the amenities also needed by the community are sport's facilities which is also the priority to be improved according to local needs.

\section{iv. Programs of Cash for Works Fulfilled Community's Aspiration}

Development is planned based on people's needs, of course, people may get benefits for their social life. Development that has been done at the moment for island community such as a permanent jetty, sports facilities, freshwater program, and so forth has brought a different view than from previous development. People feel more suitable to their basic needs so that they are not confused to physical development implementation by the government that contradict to what they need. The government always makes a contra-productive policy for people's requirements. For instance, the development of freshwater refinery from seawater source cannot be applied due to the high-cost reason. Then the technology should be done by professionals so that the program will be more beneficial to the people. However, the government provides such as a small fish oven for fishermen and it does not follow people's requirements, because the help is always focused on fisherman group; but people are accustomed to drying their fish by themselves. This action causes the government's help is useless and does not solve the current problems faced by people in Dendun village. By using development based on cash for work for Dendun people, the village budgetary fund is hoped to fulfil their needs and enhance their quality of life.

\section{v. The Cash for Work Program Allows People to have Power to Determine Development in the Village}

People's involvement is started from the meeting at a village level by conveying development aspiration based on social needs and then stipulated in the small town meeting and budgeted in the meeting at upper level. All the processes involved the people of Dendun village. It means the development based on cash for work involving people, by people, for people. It is different from the previous situation where development was not based on cash for work, so local people have no power to determine development in Dendun village. Development is decided by the government and involves another party beyond the village.

\section{vi. Physical Development on Cash For Work Basis has Opened Job Opportunity to Local People.}

Development by using village budgetary fund on cash for work basis has given the job opportunity for the people of Dendun. The majority of people work as fishermen but some of 
them do not have fishing equipment such as a boat. Therefore, they will joint projects work by getting incentive from village budgetary fund particularly during monsoon season. It is usually from May to June every year where the sea is believed in shortage of fish in this season. The former top-down development pattern causes local people to be the viewer while the workers involved are the outsiders. Today's development has involved local people as the employees.

\section{Recommendation}

The government must keep physical development on cash for work basis because it can empower local people. By development based on cash for work, the government can involve people from the meeting at village level to the small town meeting. Finally, decisions from community will be achieved where the community development program derive from the village budgetary fund. All processes from the beginning till the end, will involve local community and it will focus on the needs of people which is easier to work on. Furthermore, local community have the authority to determine the development of the village and the cash for work program will create job opportunities for them. The important recommendation is the cash for work basis must be from community or society because having local people's involvement only as workers while materials for development provided by the third party will only give advantage for the third party. The government must allocate and identify the suppliers at small town level to facilitate materials needed in physical development to ensure the community will not rely on a third party in supplying materials for the development of Dendun village.

\section{References}

Roman, A. (2020). Changing People, Changing Lives Through Public Participation and Social Transformation: A South African Case Study of a Rural Development Programme. South African Journal of Political Studies, Vol 47 (2), 253-268, 2020

Samah, A. A., \& Aref, F. (2009). People's Participation In Community Development: A Case Study In A Planned Village Settlement In Malaysia. World Rural Observations, Vol 1 (2), 45-54.

Budiasa, R. (2020). Implementasi Kebijakan Padat Karya Tunai (PKT) Pada Masyarakat Miskin di Desa Lebih, Gianyar. Ejournal Warmadewa.ac.id

Devi, M. (2013). Peran Kepemimpinan Kepala Desa Dalam Pembangunan Infrastruktur Desa Dendun Kabupaten Bintan Tahun 2011-2013. Jurnal.Umrah.ac.id

Dian, M. (2019). Pemberdayaan Masyarakat Melalui Program Padat Karya Tunai (Study Kasus Desa Plandaan Kecamatan Kedungwaru Kabupaten Tulungagung. Journal Publika, Vol 7, No 4 (2019).

Cristian, H. (2015). Studi Tentang Pelaksanaan Rencana Kerja Pembangunan Desa (Rkpdes) Tahun 2013 Di Desa Loa Janan Ulu Kecamatan Loa Janan Kabupaten Kutai Kartanegara. eJournal Pemerintahan Integratif, 2015, 3 (1) ; 190-210.

Hanani, S. (2017). Keterlibatan Perempuan Dalam Kepemimpinan Publik: Studi Kepemimpinan Ketua RT Perempuan Di Desa Dendun Kepulauan Riau. Kafa'ah Journal, 7 (1), 2017, (79-92).

Tantoh, H. B., Simatele, D. (2017). Community Based Water Resource Management In NorthWest Cameroon: The Role Of Potable Water Supply In Community Development. South African Geographical Journal, 99 (2), 166-183. 
Embong, A. H., Khairuldin, W. M. K. F. W., Yasin, M. F. M., Hassan, A., \& Ibrahim, M. S. (2021, March). Between Reformist and Interpretation: Notes on Hamka's Methodological Strategies as Reformist Mufassir. In First International Conference on Science, Technology, Engineering and Industrial Revolution (ICSTEIR 2020) (pp. 415-422). Atlantis Press.

Majid, S. F., Khairuldin, W., \& Ajmain, M. T. (2019). Fiqh Boycott On LGBT Community: A Review. Perdana: International Journal of Academic Research, 6(2), 35-49.

Anas, W. N. I. W. N., Daud, N., Khairul, W. M., \& Khairuldin, F. W. (2017). The Stance of Alimony or Maintenance for Working Wives within Working Period: An Analysis from the Qualified Jurists (Muftis). International Journal of Academic Research in Business and Social Sciences, 7(4), 2222-6990.

Hassan, S. A., \& Khairuldin, W. (2020). Research Design Based on Fatwa Making Process: An Exploratory Study. International Journal of Higher Education 9 (6), 241-246

Hudson. (2020). An Exploration of The Physical Activity Experiences of Northern Aboriginal Youth: A Community-Based Participatory Research Project. Journal Qualitative Research in Sport, Exercise and Health , Vol 12 (1), 108-124.

Khin, Z. W. (2019). Effectiveness of National Community-Driven Development Project on Communities in Kyauk Kyi Township. Yangon University of Economics.

Nuttavuthisit, K. (2015). Participatory Community Development: Evidence from Thailand. Community Development Journal, 50 (1), 55-70.

Mardikanto. (2014). Pengembangan Masyarakat. Surakarta: UNS Press.

Zaini, R. (2016). Sosiologi Pembangunan. Indonesia: Penerbit Ombak.

Bekun, S. G.,\& Makmur. (2013). Strategi Pelaksanaan Program Padat Karya Pangan Dalam Meningkatkan Pemberdayaan Masyarakat Desa di KabupatenTimor Tengah Utara. Journal Sosial dan Humaniora, Vol 16, No 2 (2013).

Sumarto, D. (2019). Pemanfaatan Dana Desa Untuk Peningkatan Taraf Hidup Masyarakat Pedesaan Melalui Pemberdayaan Masyarakat Desa. Journal Publicuho 2 (2), 65-74 2019.

Theresia. (2014). Pembangunan Berbasis Masyarakat, Acuan Bagi Praktisi, Akademisi, dan Pemerhati Pengembangan Masyarakat. Penerbit: Alfabeta Bandung.

Nyaguthi, W. E., \& Oyugi, L. A. (2013). Influence Of Community Participation On Successful Implementation Of Constituency Development Fund Project In Kenya: Case Study Of Mwea Constituency. International Journal of Education and Research 1 (8), 1-16. 2013. 